\title{
PROGRAM MATRIKULASI PADA PEMBELAJARAN KURIKULUM 2013
}

\author{
Salma Sunaiyah \\ Institut Agama Islam Negeri (IAIN) Kediri \\ e-mail: salmasunaiyah8@gmail.com
}

\begin{abstract}
Matriculation program as learning model for different student is applied by activities. The first matriculation activity is discussion. The goal of this discussion is student can find information from books, internet, and discussion. In this small discussion, there is product as a result. The discussion is done for hour of meeting. The next activity is presentation, plus value from this model is student can find more detail information through direct reading. Student more understand and give quality question. The goal of matriculation is sharpen sensitiveness for analysis and study how to give conclusion scientifically.
\end{abstract}

Matrikulasi sebagai model pembelajaran untuk siswa yang input-nya berbeda-beda dilaksanakan melalui beberapa kegiatan. Kegiatan matrikulasi dilaksanakan pertama-tama dengan kegiatan diskusi matrikulasi. Diskusi matrikulasi dimaksudkan agar peserta didik mampu menemukan informasi dari buku, internet, dan berdiskusi. Dalam diskusi kecil ada hasilnya berupa produk. Diskusi dilaksanakan selama satu jam pelajaran. Satu jam pelajaran berikutnya adalah waktu untuk melaksanakan presentasi atau dan panel. Kelebihan dari model ini (matrikulasi), siswa dalam kelompoknya menemukan informasi lebih detail melalui proses membaca langsung. Siswa lebih memahami dan mengajukan pertanyaan secara lebih berkualitas. Tingkat pertanyaan menunjukkan pemahaman mereka. Tujuan dari matrikulasi adalah menajamkan kepekaan analisis dan belajar menarik kesimpulan secara ilmiah. Presentasi hasil diskusi dengan cara siswa menjelaskan dan bertanya jawab lalu menyimpulkan materi yang didiskusikanya. Melalui model ini, efektifitas dapat dicapai. Siswa mengalami sendiri proses scientific dan hasil kognitif pun lebih tinggi kualitasnya. 
Salma Sunaiyah

Keywords: Matriculation, Learning, Kurikulum 2013

\section{Pendahuluan}

Matrikulasi merupakan kegiatan yang dilakukan untuk memenuhi kekurangan atau kesenjangan (defisiensi) dalam pengetahuan dan keterampilan yang berfungsi sebagai kemampuan awal (entry behavior) yang diperlukan peserta didik untuk mengikuti kegiatan pembelajaran pada jenjang tertentu dengan baik. Matrikulasi diperlukan manakala peserta didik dengan latar belakang beragam belum memiliki pengetahuan dan kemampuan dasar yang dipersyaratkan. Program matrikulasi bertujuan untuk mencapai entry level yang sama bagi seluruh peserta didik, berisi pemantapan materi yang seharusnya sudah dikuasai. ${ }^{1}$

Akan tetapi konsep matrikulasi ini dapat juga digunakan sebagai model pembelajaran dalam proses pembelajaran pada seluruh mata pelajaran. Pelaksaan Kurikulum 2013 pada semua satuan pendidikan didasarkan pada Surat Edaran Menteri Pendidikan dan Kebudayaan (SE Mendikbud) Nomor 156928/MPK.A/KR/2013 tahun 2013 yang mengamanatkan bahwa pada tahun pelajaran 2014/2015 bersama Kementerian Agama akan mengimplementasikan Kurikulum 2013 pada semua satuan pendidikan: SD/MI I, II, IV, dan V; SMP/MTs

\footnotetext{
1 Direktorat Pembinaan Sekolah Menengah Atas, Direktorat Jenderal Pendidikan Menengah, Panduan Matrikulasi di SMA Tahun 2014 (Jakarta: Kementerian Pendidikan dan Kebudayaan, 2014), 7.
} 
kelas VII dan VIII; SMA/MA/SMK/MAK kelas X dan XI di seluruh Indonesia. ${ }^{2}$

Pada tahun pelajaran 2013/2014 SMA yang telah melaksanakan Kurikulum 2013 sebanyak 1270 sekolah. Dari 11.629 SMA di Indonesia baru 10\% yang melaksanakan Kurikulum 2013, ini berarti bahwa belum semua peserta didik kelas XI pada tahun pelajaran 2014/2015 menerima kompetensi dasar yang sama sebagaimana peserta didik kelas XI yang mengikuti Kurikulum 2013 sejak tahun pelajaran 2013/2014. Mata pelajaran di kelas $\mathrm{X}$ yang termuat dalam Permendiknas No. 22 tahun 2006 tentang Standar Isi dan mata pelajaran kelas X yang termuat dalam Permendikbud No. 69 tahun 2013 tentang Kerangka Dasar dan Struktur Kurikulum memiliki jenis dan jumlah berbeda. ${ }^{3}$

Konsekuensinya para guru mata pelajaran pada tahun pelajaran 2013/2014 belum melaksanakan Kurikulum 2013 perlu mempersiapkan manajemen upaya pemenuhan kompetensi siswa kelas XI disesuaikan dengan kompetensi Kurikulum 2013. Salah satu upaya yang dapat dilakukan adalah melakukan program matrikulasi bagi kelas XI untuk kompetensi kelas X yang belum sesuai dengan tuntutan kurikulum 2013, dan menyamakan kemampuan awal siswa menuju materi inti.

Berpijak dari paparan di atas, maka perlu dipaparkan tentang bagaimana langkah-langkah matrikulasi yang digunakan

\footnotetext{
${ }^{2}$ Direktorat Pembinaan SMA, Panduan Matrikulasi, 4.

${ }^{3}$ Direktorat Pembinaan SMA, Panduan Matrikulasi, 7.
} 
sebagai model pembelajaran untuk siswa yang input-nya berbeda-beda dan bertujuan mencapai ketuntasan belajar. Tulisan ini diharapkan dapat membantu para guru dalam kegiatan pembelajaran pada Kurikulum 2013 khususnya untuk kelas yang mempunyai masalah siswa yang input-nya berbedabeda dan bertujuan mencapai ketuntasan belajar.

\section{Konsep Matrikulasi}

Konsep matrikulasi bukanlah konsep asing dalam dunia pendidikan. Matrikulasi dikenal sebagai program aanvullen atau matriculation yang berarti pemenuhan kekurangan. Matrikulasi merupakan kegiatan yang dilakukan untuk memenuhi kekurangan atau kesenjangan (defisiensi) dalam pengetahuan dan keterampilan yang berfungsi sebagai kemampuan awal (entry behavior) yang diperlukan peserta didik untuk mengikuti kegiatan pembelajaran pada jenjang tertentu dengan baik. Matrikulasi diperlukan manakala peserta didik dengan latar belakang beragam belum memiliki pengetahuan dan kemampuan dasar yang dipersyaratkan. Program matrikulasi bertujuan untuk mencapai entry level yang sama bagi seluruh peserta didik, berisi pemantapan materi yang seharusnya sudah dikuasai. $^{4}$

Menurut Kamus Besar Bahasa Indonesia, matrikulasi berarti hal terdaftarnya seseorang di Perguruan Tinggi atau penyetaraan ilmu yang ditujukan bagi calon mahasiswa yang

\footnotetext{
${ }^{4}$ Direktorat Pembinaan SMA, Panduan Matrikulasi, 7.
} 
dianggap belum mempunyai dasar keilmuan yang cukup untuk mengikuti perkuliahan. ${ }^{5}$ Dari definisi-definisi yang ada, Tim Kurikulum Direktorat Pembinaan SMA mengartikan matrikulasi di SMA sebagai kegiatan pembelajaran untuk menyetarakan penguasaan kompetensi peserta didik kelas XI yang pada waktu mereka berada di kelas X tahun pelajaran 2013/2014 belum mengikuti Kurikulum 2013 sehingga pada tahun pelajaran 2014/2015 dapat mengikuti program pembelajaran kelas XI sesuai Kurikulum 2013. ${ }^{6}$

Secara operasional program matrikulasi diartikan sebagai kegiatan pemenuhan kompetensi peserta didik agar kesenjangan antara muatan atau substansi dan pengalaman belajar (learning experience) dari kurikulum yang berbeda dapat dipenuhi sesuai dengan kompetensi yang harus dipenuhi. Kegiatan ini harus dikelola satuan pendidikan secara terencana, terarah, terprogram, dan dapat dipertanggungjawabkan. Oleh karena itu, Direkorat Pembinaan SMA memberikan panduan yang dapat dijadikan rujukan dalam melaksanakan program tersebut. Melalui analisis dan identifikasi kompetensi peserta didik secara cermat, dapat diperoleh dua kelompok peserta didik dengan tindakan berbeda, yaitu kelompok peserta didik yang perlu dan tidak perlu mengikuti matrikulasi. ${ }^{7}$

\footnotetext{
5 Badan Pengembangan dan Pembinaan Bahasa, "KBBI Daring" Kementerian Pendidikan dan Kebudayaan Republik Indonesia dalam https://kbbi.kemdikbud.go.id/entri/nul

${ }^{6}$ Direktorat Pembinaan SMA, Panduan Matrikulasi, 7.

${ }^{7}$ Direktorat Pembinaan SMA, Panduan Matrikulasi, 8.
} 
Satuan pendidikan dapat menerapkan pola matrikulasi mata pelajaran melalui beberapa cara atau pertimbangan, antara lain: uji kompetensi untuk seluruh mata pelajaran, uji kompetensi untuk mata pelajaran tertentu dan penugasan untuk mata pelajaran lainnya (sesuai karateristik), tanpa uji kompetensi dan penugasan (seluruh peserta didik mengikuti pembelajaran matrikulasi untuk semua mata pelajaran). Matrikulasi bagi mata pelajaran yang dapat ditempuh melalui penugasan untuk mendapatkan nilai pengetahuan diambil dari hasil tes dan penugasan, nilai keterampilan dapat dari proyek atau portofolio, dan nilai sikap dapat dari penilaian antar teman. Matrikulasi bagi mata pelajaran yang ditempuh melalui uji kompetensi untuk mendapatkan nilai pengetahuan diambil dari hasil tes, nilai keterampilan dapat dari portofolio, dan nilai sikap dapat dari penilaian antar teman. Matrikulasi melalui pembelajaran utuh, semua aspek yang dinilai disesuaikan dengan penilaian pada Kurikulum 2013 secara utuh. Peserta didik yang tidak lulus uji kompetensi atau penugasan wajib mengikuti matrikulasi pembelajaran yang diakhiri dengan uji kompetensi. Peserta didik yang tidak lulus uji kompetensi wajib mengikuti program remedial. Nilai ketuntasan uji kompetensi sesuai dengan Kriteria Ketuntasan Minimal (KKM) mata pelajaran bersangkutan pada tahun pelajaran 2013/2014. Penilaian pada SMA pelaksana SKS mengikuti pola yang berlaku di satuan pendidikan bersangkutan. ${ }^{8}$

\footnotetext{
${ }^{8}$ Direktorat Pembinaan SMA, Panduan Matrikulasi, 9.
} 
Matrikulasi mata pelajaran dapat dilakukan dalam beberapa bentuk, antara lain: Pertama, kegiatan pembelajaran tatap muka, penugasan terstruktur, dan kegiatan mandiri secara utuh dalam periode waktu tertentu. Bentuk kegiatan pertama dilakukan dengan cara menambah jam pelajaran pada jadwal mata pelajaran atau menjadwalkan khusus di luar jadwal mata pelajaran. Hal ini dilakukan melalui proses pembelajaran utuh karena pertimbangan kompetensi yang harus dikuasai memerlukan waktu dan proses yang utuh.

Kedua, kegiatan pembelajaran tatap muka, penugasan terstruktur, dan kegiatan mandiri secara terbatas dalam periode waktu tertentu. Bentuk kegiatan kedua dilakukan dengan membuat jadwal tertentu di luar jadwal mata pelajaran. Hal ini dilakukan melalui proses pembelajaran tatap muka terbatas untuk beberapa kompetensi dasar, sementara kompetensi dasar lainnya dapat dilakukan dengan penugasan.

Ketiga, kegiatan penugasan terstruktur dan kegiatan mandiri. Bentuk kegiatan ke tiga dilakukan cukup dengan memberikan penugasan kepada peserta didik pada beberapa kompetensi dasar sampai kompetensi itu dikuasai. Kegiatan ini dilakukan apabila semua kompetensi yang harus dikuasai pada mata pelajaran terkait dapat dilakukan melalui penugasan. ${ }^{9}$

\footnotetext{
${ }^{9}$ Direktorat Pembinaan SMA, Panduan Matrikulasi, 15-16.
} 
Salma Sunaiyah

\section{Konsep Kurikulum 2013}

Secara etimologis, kurikulum berasal dari bahasa Latin curerer yaitu pelari, dan curere yang artinya tempat berlari. Pada awalnya kurikulum diartikan sebagai suatu jarak yang harus ditempuh oleh pelari mulai dari garis start sampai dengan finish. Kemudian pengertian kurikulum tersebut digunakan dalam dunia pendidikan dengan pengertian sebagai "rencana dan pengaturan tentang sejumlah mata pelajaran yang harus dipelajari peserta didik dalam menempuh pendidikan di lembaga pendidikan". 10

Pengertian kurikulum sebagaimana yang dijelaskan dalam Undang-undang Nomor 20 tahun 2003 tentang Sistem Pendidikan Nasional adalah "seperangkat rencana dan pengaturan mengenai tujuan, isi, dan bahan pelajaran serta cara yang digunakan sebagai pedoman penyelenggaraan kegiatan pembelajaran untuk mencapai tujuan pendidikan tertentu". 11

Kurikulum merupakan salah satu unsur yang bisa memberikan kontribusi yang signifikan dalam mewujudkan proses berkembangnya kualitas potensi peserta didik. Jadi tidak dapat disangkal bahwa kurikulum yang dikembangkan dengan berbasis pada kompetensi sangat diperlukan sebagai instrumen untuk mengarahkan peserta didik menjadi manusia berkualitas yang mampu dan proaktif menjawab tantangan zaman yang

\footnotetext{
${ }^{10}$ Imas Kurniasih dan Berlin Sani, Implementasi Kurikulum 2013: Konsep dan Penerapan (Surabaya: Kata Pena, 2014), 128.

${ }^{11}$ Undang-undang Republik Indonesia Nomor 20 Tahun 2003 tentang Sistem Pendidikan Nasional, Bandung: Fokusmedia, 2010.
} 
selalu berubah, manusia terdidik yang beriman dan bertakwa kepada tuhan yang maha esa, berakhlak mulia, sehat, berilmu, cakap, kreatif dan mandiri dan warga negara yang demokratis dan bertanggung jawab.

Orientasi kurikulum 2013 adalah terjadinya peningkatan dan keseimbangan antara kompetensi sikap, keterampilan dan pengetahuan. Hal itu sejalan dengan amanat Undang-undang nomor 20 tahun 2003 sebagaimana tersurat dalam penjelasan pasal 35: "kompetensi lulusan merupakan kualifikasi kemampuan lulusan yang mencakup sikap, pengetahuan, dan keterampilan sesuai dengan standar yang telah disepakati”. ${ }^{12} \mathrm{Hal}$ ini sejalan pula dengan pengembangan kurikulum berbasis kompetensi yang telah dirintis pada tahun 2004 dengan mencakup kompetensi sikap, pengetahuan, dan keterampilan secara terpadu.

Pengertian Kurikulum 2013 adalah kurikulum yang melakukan penyederhanaan, dan tematik-integratif, menambah jam pelajaran dan bertujuan untuk mendorong peserta didik, mampu lebih baik dalam melakukan observasi, bertanya, bernalar, dan mengkomunikasikan (mempresentasikan), apa yang peserta didik peroleh atau ketahui setelah menerima materi pembelajaran dan diharapkan peserta didik memiliki kompetensi sikap, keterampilan, dan pengetahuan jauh lebih baik, serta akan lebih kreatif, inovatif, dan lebih produktif, sehingga nantinya

\footnotetext{
${ }^{12}$ Undang-undang Republik Indonesia Nomor 20 Tahun 2003 tentang Sistem Pendidikan Nasional, Bandung: Fokusmedia, 2010.
} 
peserta didik bisa sukses dalam menghadapi berbagai persoalan dan tantangan di zamannya, memasuki masa depan yang lebih baik.

Penerapan kurikulum 2013 diimplementasikan adanya penambahan jam pelajaran, hal tersebut sebagai akibat dari adanya perubahan proses pembelajaran yang semula dari siswa diberi tahu menjadi siswa yang mencari tahu. Selain itu, akan merubah pula proses penialaian yang semula berbasis output menjadi berbasis proses dan output. Titik berat kurikulum 2013 adalah bertujuan agar peserta didik memiliki kemampuan yang lebih baik dalam melakukan: observasi, bertanya (wawancara), bernalar, mengkomunikasikan (mempresentasikan) apa yang peserta peroleh atau ketahui setelah menerima materi pembelajaran. $^{13}$

Konsep kurikulum 2013 menekankan pada aspek kognitif, afektif, psikomotorik melalui penilaian berbasis tes dan portofolio saling melengkapi. Kurikulum ini akan diterapkan untuk seluruh lapisan pendidikan, mulai dari Sekolah Dasar hingga Sekolah Menengah Atas maupun Sekolah Menengah Kejuruan. Dalam kurikulum ini, siswa untuk semua mata pelajaran sudah tidak lagi banyak menghafal, tapi lebih banyak kurikulum berbasis sains.

Pada intinya, orientasi pengembangan kurikulum 2013 adalah tercapainya kompetensi yang berimbang antara sikap, keterampilan, dan pengetahuan, serta cara pembelajarannya

\footnotetext{
${ }^{13}$ Kurniasih dan Berlin Sani, Implementasi Kurikulum 2013, 132.
} 
yang holistik dan menyenangkan. Kurikulum 2013 lebih menekankan pada dimensi pedagogik modern dalam pembelajaran, yaitu menggunakan pendekatan ilmiah. Pendekatan ilmiah tersebut meliputi, mengamati, menanya, menalar, mencoba, dan membentuk jejaring. Secara konseptual kurikulum 2013 jelas ada perubahan signifikan. Perubahan itu tentunya dimaksudkan untuk menjadikan pendidikan menjadi lebih baik.

Kurikulum 2013 dirancang dengan tujuan untuk mempersiapkan insan Indonesia supaya memiliki kemampuan hidup sebagai pribadi dan warga negara yang beriman, produktif, kreatif, inovatif dan afektif serta mampu berkontribusi pada kehidupan bermasyarakat, berbangsa, bernegara dan peradaban dunia. Kurikulum adalah instrumen pendidikan untuk dapat membawa insan Indonesia memiliki kompetensi sikap, pengetahuan, dan keterampilan sehingga dapat menjadi pribadi dan warga negara yang produktif, kreatif, inovatif, dan afektif. Menurut Kuhlthau, Maniotes dan Caspari dalam Yunus Abidin bahwa model pembelajaran proses saintifik dalam prakteknya siswa diharuskan melakukan serangkaian aktivitas selayaknya langkah-langkah penerapan metode ilmiah. Serangkaian aktivitas yang dimaksud meliputi merumuskan masalah, mengajukan hipotesis, mengumpulkan data, dan membuat kesimpulan. $^{14}$

${ }^{14}$ Yunus Abidin, Desain Sistem Pembelajaran dalam Konteks Kurikulum 2013 (Bandung: PT. Refika Aditama, 2014), 125. 
Singkatnya, kurikulum 2013 adalah kurikulum yang melakukan penyederhanaan, dan tematik-integratif, menambah jam pelajaran dan bertujuan untuk mendorong peserta didik, mampu lebih baik dalam melakukan observasi, bertanya, bernalar, dan mengkomunikasikan (mempresentasikan), apa yang peserta didik peroleh atau ketahui setelah menerima materi pembelajaran dan diharapkan peserta didik memiliki kompetensi sikap, keterampilan, dan pengetahuan jauh lebih baik, serta akan lebih kreatif, inovatif, dan lebih produktif, sehingga nantinya peserta didik bisa sukses dalam menghadapi berbagai persoalan dan tantangan di zamannya, memasuki masa depan yang lebih baik. Sedangkan, desain sistem pembelajaran dalam konteks kurikulum 2013 harus diawali dengan kegiatan studi pendahuluan untuk merumuskan tujuan pembelajaran. ${ }^{15}$

Pelaksananaan pembelajaran merupakan implementasi dari RPP yang meliputi kegiatan pendahuluan, kegiatan inti dan penutup". ${ }^{16}$ Kegiatan pendahuluan terdiri dari beberapa rangkaian kegiatan, antara lain: menyiapkan peserta didik secara psikis dan fisik untuk mengikuti proses pembelajaran, memberi motivasi belajar siswa secara kontekstual sesuai manfaat dan aplikasi materi ajar dalam kehidupan sehari-hari, dengan memberikan contoh dan perbandingan lokal, nasional dan internasional, mengajukakn pertanyaan-pertanyaan yang

\footnotetext{
${ }^{15}$ Abidin, Desain Sistem Pembelajaran, 53

${ }^{16}$ Hosnan, Pendekatan Saintifik dan Kontekstual dalam Pembelajaran Abad

21 (Bogor: Ghalia Indonesia, 2014), 1-3.
} 
mengaitkan pengetahuan sebelumnya dengan materi yang akan dipelajari, menjelaskan tujuan pembelajaran atau kompetensi dasar yang akan dicapai, dan menyampaikan cakupan materi dan penjelasan uraian kegiatan sesuai silabus.

Selanjutnya adalah kegiatan inti yang merupakan proses pembelajaran untuk mencapai tujuan, dilakukan secara interaktif, inspiratif, menyenangkan, menantang, memotivasi peserta didik untuk secara aktif menjadi pencari informasi, serta memberikan ruang yang cukup bagi prakarsa, kreativitas, dan kemandirian sesuai dengan bakat, minat dan perkembangan fisik serta psikologis peserta didik. Penggunaan metode pada kegiatn inti disesuaikan dengan karakteristik peserta didik dan mata pelajaran (proses observasi, menanya, mengumpulkan informasi, asosiasi, dan komunikasi). Adapun Kompetensi Dasar (KD) yang bersifat prosedur untuk melakukan sesuatu, guru memfasilitasi agar peserta didik dapat melakukan pengamatan terhadap pemodelan/demonstrasi oleh guru atau ahli, peserta didik menirukan, selanjutnya guru melakukakn pengecekan dan pemberian umpan balik, dan latihan lanjutan kepada peserta didik.

Dalam setiap kegiatan, guru harus memperhatikan kompetensi yang terkait dengan sikap, seperti jujur, teliti, kerjasama, toleransi, disiplin, taat aturan, menghargai pendapat orang lain yang tercantum dalam silabus dan RPP. Cara pengumpulan data sedapat mungkin relevan dengan jenis data yang dieksplorasi, misalnya di laboratorium, studio, lapangan, 
perpustakaan, museum, dan sebagainya. Sebelum menggunakannya, peserta didik harus tahu dan terlatih, dilanjutkan dengan menerapkannya. Kegiatan inti menggunakan model pembelajaran, metode pembelajaran, media pembelajaran, dan sumber belajar yang disesuaikan dengan karakteristik peserta didik dan mata pelajaran. Pemilihan pendekatan tematik dan/atau tematik terpadu dan/atau saintifik dan/atau inkuiri dan discovery dan/atau pembelajaran yang menghasilkan karya berbasis pemecahan masalah project based learning) disesuaikan dengan karakteristik kompetensi dan jenjang pendidikan.

Kegiatan inti terdiri dari "mengamati, menanya, mengumpulkan dan mengasosiasikan, dan mengkomunikasikan hasil". ${ }^{17}$ Pertama, mengamati. Dalam kegiatan mengamati, guru membuka secara luas dan bervariasi kesempatan peserta didik untuk melakukan pengamatan melalui kegiatan: melihat, menyimak, mendengar, dan membaca. Guru juga memfasilitasi peserta didik untuk melakukan pengamatan, melatih mereka untuk memperhatikan (melihat, membaca, mendengar) hal yang penting dari suatu benda atau objek. Contoh kegiatan mengamati dan mendeskripsikan, yaitu: mendorong siswa untuk melakukan pengamatan (menghitung, mengukur, membandingkan, dan seterusnya). Membantu siswa agar mampu menuliskan atau mendeskripsikan hasil pengamatannya, misalnya melukiskan

\footnotetext{
${ }^{17}$ Hosnan, Pendekatan Saintifik, 1-3.
} 
atau meiru (trace), menuliskan hasil perhitungan atau pengukuran pada gambar, dan mendeskripsikan gambar.

Kedua, menanya. Dalam kegiatan ini, guru membuka kesempatan secara luas untuk bertanya mengenai apa yang sudah dilihat, disimak, dibaca, dan seterusnya. Kemudian guru membimbing mereka untuk dapat mengajukan pertanyaan (hasil pengamatan objek yang konkret sampai yang abstrak berkenaan dengan fakta, konsep, prosedur, ataupun hal lain yang lebih abstrak. Pertanyaan bersifat faktual sampai ke yang bersifat hipotetik. Guru perlu membantu peserta didik untuk mengajukan pertanyaan sampai ke tingkat di mana mereka mampu mengajukan pertanyaan secara mandiri. Semakin terlatih dalam bertanya maka rasa ingin tahu semakin dapat dikembangkan. Contoh kegiatan menanyakan dan menganalisis antara lain: siswa membuat pertanyaan, misalnya: Bagaimana kalau jaringnya dibuat dua kali lipat besarnya? Apakah mungkin jaringya dibuat lebih ringan, tapi kuat? Bagaimana supaya kegiatan memancingnya lebih aman dan lebih mengasyikkan? dan sebagainya. Selanjutnya guru juga harus mampu mendorong siswa untuk menemukan faktor-faktornya: misalnya; Kalau dua kali lipat besarnya, apanya saja yang berubah? Bahan apa yang ringan tapi kuat? Kapan aman dan asyik? Apa saja yang perlu dipikirkan?

Ketiga, mengumpulkan dan mengasosiasikan. Tindak lanjut dari bertanya adalah menggali dan mengumpulkan informasi dari berbagai sumber melalui berbagai cara (membaca 
buku yang lebih banyak, memperhatikan fenomena atau objek yang lebih teliti, atau bahkan melakukan eksperimen). Informasi yang diperoleh menjadi dasar bagi kegiatan berikutnya (memproses informasi untuk menemukan keterkaitan satu informasi dengan informasi lainnya, kemudian mengambil berbagai kesimpulan). Kegiatan menggali informasi terdiri dari beragam cara, antara lain: menyediakan bahan bacaan/sumber informasi untuk belajar, menyediakan narasumber, mengajak siswa merancang percobaan dan melakukannya, mengajak siswa berpikir kritis dan analitis. Selain itu, kegiatan ini juga terdiri dari mempersiapkkan diri, antara lain: mendorong siswa untuk memilih format presentasi yang terbaik mereka, membantu siswa mengembangkan presentasinya (alur, dan kalimatkalimatnya), menetapkan tempat presentasi masing-masing dan melakukan simulasi (jika diperlukan).

Keempat, mengkomunikasikan hasil. Kegiatan ini merupakan kegiatan lanjutan berupa kegiatan menuliskan atau menceritakan apa yang ditemukan dalam kegiatan mencari informasi, mengasosiasikan dan menemukan pola. Selanjutnya hasil penulisan disampaikan di kelas dan dinilai oleh guru sebagai hasil belajar secara individu atau kelompok. Bentuk kegiatan menyampaikan/mengkomunikasikan hasil dapat dilakukan dengan beragam bentuk, misalnya: memasang dan memajangkan hasil karya siswa, mengajak anak bergantian mempresentasikan dan saling berkunjung pada hasil kerja temannya, mengadakan lomba pajangan terbaik (menurut versi 
siswa, menurut versi guru, menurut versi pengunjung luar), mengadakan pemberian hadiah/reward penghargaan bagi siswa.

Terakhir adalah kegiatan penutup. Dalam kegiatan penutup, guru bersama siswa baik secara individual maupun kelompok melakukan refleksi untuk mengevaluasi seluruh rangkaian aktivitas pembelajaran dan hasil-hasil yang diperoleh untuk selanjutnya secara bersama menemukan manfaat langsung maupun tidak langsung dari hasil pembelajaran yang telah berlangsung, memberikan umpan balik terhadap proses dan hasil pembelajaran, melakukan kegiatan tindak lanjut dalam bentuk pemberian tugas, baik tugas individual maupun kelompok; dan menginformasikan rencana kegiatan pembelajaran untuk pertemuan berikutnya.

\section{Proses Pembelajaran Model Matrikulasi}

Untuk mengatasi masalah siswa yang input-nya berbedabeda dan mencapai ketuntasan, guru mata pelajaran dapat menggunakan model matrikulasi, yaitu melalui langkah-langkah sebagai berikut:

1. Kegiatan matrikulasi dilaksanakan pertama-tama dengan kegiatan diskusi matrikulasi. Yaitu siswa menemukan informasi dari buku, internet, dan berdiskusi. Dalam diskusi kecil ada hasilnya berupa produk. Diskusi dilaksanakan selama 1 jam pelajaran. 1 jam berikutnya presentasi atau dan panel. Kelebihan dari metode ini (matrikulasi), siswa dalam kelompoknya menemukan 
informasi lebih detail melalui proses membaca langsung. Siswa lebih memahami dan mengajukan pertanyaan secara lebih berkualitas. Tingkat pertanyaan menunjukkan pemahaman mereka. Tujuan dari matrikulasi adalah menajamkan kepekaan analisis dan belajar menarik kesimpulan secara ilmian.

2. Presentasi hasil diskusi dengan cara siswa menjelaskan dan bertanya jawab lalu menyimpulkan materi yang didiskusikannya. Melalui metode ini, efektifitas dapat dicapai. Siswa mengalami sendiri proses scientific dan hasil kognitif pun lebih tinggi kualitasnya. ${ }^{18}$

Berdasarkan hasil penelitian penulis, produk yang dihasilkan sudah sesuai harapan dan memenuhi standar sesuai yang diharapkan kurikulum 2013. Siswa mengamati, menanya, menalar, mencoba, dan membentuk jejaring untuk semua mata pelajaran.

\section{Penutup}

Proses pembelajaran dengan model matrikulasi dapat digunakan sebagai solusi dari permasalahan siswa yang inputnya berbeda-beda untuk mencapai ketuntasan belajar. Proses pembelajaran model matrikulasi dalam konteks Kurikulum 2013 dilaksanakan pertama-tama dengan kegiatan diskusi matrikulasi yang dimaksudkan agar siswa menemukan informasi dari buku, internet, dan berdiskusi kecil. Hasil dari diskusi kecil adalah

${ }^{18}$ MAN 3, Observasi, Kota Kediri. 
penemuan informasi dari berbagai sumber oleh peserta didik secara mandiri yang selanjutnya dipresentasikan. Hasil proses pembelajaran melalui model ini, efektifitas dapat dicapai. Siswa mengalami sendiri proses scientific dan hasil kognitif pun lebih tinggi kualitasnya.

\section{Daftar Rujukan}

Abidin, Yunus. Desain Sistem Pembelajaran dalam Konteks Kurikulum 2013. Bandung: PT. Refika Aditama, 2014.

Badan Pengembangan dan Pembinaan Bahasa Kementerian Pendidikan dan Kebudayaan. "KBBI Daring" dalam https://kbbi.kemdikbud.go.id/entri/nul

Direktorat Pembinaan Sekolah Menengah Atas, Direktorat Jenderal Pendidikan Menengah. Panduan Matrikulasi di SMA Tahun 2014. Jakarta: Kementerian Pendidikan dan Kebudayaan, 2014.

Hosnan. Pendekatan Saintifik dan Kontekstual dalam Pembelajaran Abad 21 (Bogor: Ghalia Indonesia, 2014.

Kurniasih, Imas dan Berlin Sani. Implementasi Kurikulum 2013: Konsep dan Penerapan. Surabaya: Kata Pena, 2014.

MA Negeri 3. Observasi. Kota Kediri.

Undang-undang Republik Indonesia Nomor 20 Tahun 2003 tentang Sistem Pendidikan Nasional. Bandung: Fokusmedia, 2010. 